\title{
PENGARUH PEMBELAJARAN KOOPERATIF TIPESTUDENT TEAMS ACHIEVEMENT DIVISIONS (STAD) TERHADAP KEMAMPUAN KONEKSI MATEMATIS
}

\author{
Sri Jayanta ${ }^{1)}$, Somakim ${ }^{2),}$ NilaKesumawati ${ }^{3)}$ \\ ${ }^{1), 2), 3)}$ Program Studi Pendidikan Matematika Universitas PGRI Palembang \\ ${ }^{1)}$ Jayanta@univpgri-palembang.ac.id \\ ${ }^{2)}$ Somakim@univsriwijaya-palembang.ac.id \\ ${ }^{3)}$ Kesumawati@univpgri-palembang.ac.id
}

\begin{abstract}
Abstrak
Penelitian ini merupakan penelitian eksperimen dengan rancangan perlakuan Posttest-Only Control Design. Populasi dalam penelitian ini yaitu seluruh kelas VII SMP Negeri 5 Palembang. Dengan teknik cluster sampling diperoleh kelas VII.7 sebagai kelas eksperimen dan kelas VII.8 sebagai kelas kontrol. Kelas eksperimen diberi perlakuan dengan model pembelajaran kooperatif tipe student teams achievement divisions (STAD), sedangkan kelas kontrol diberi perlakuan dengan pembelajaran konvensional. Teknik pengumpulan data menggunakan tes. Teknik analisis data menggunakan uji $t$ (independent sampel t-test), dengan terlebih dahulu menguji normalitas dan homogenitas. Berdasarkan hasil analisis tes kemampuan koneksi matematis menunjukkan bahwa ada pengaruh model pembelajaran kooperatif tipe student teams achievement divisions (STAD) terhadap kemampuan koneksi matematissiswa SMP Negeri 5 Palembang.
\end{abstract}

Kata kunci: STAD, Kemampuan, Koneksi, Matematis

\begin{abstract}
This research is an experimental study with the treatment design of Posttest-Only Control Design. The population in this study is all class VII Palembang 5 State Middle School. The cluster sampling technique obtained class VII.7 as the experimental class and class VII.8 as the control class. The experimental class was treated with cooperative learning model type student teams achievement divisions (STAD), while the control class was treated with conventional learning. Data collection techniques use tests. Data analysis technique uses $t$ test (independent sample t-test), by first testing normality and homogeneity. Based on the results of the mathematical connection ability test shows that there is an influence of cooperative learning model type student teams achievement divisions (STAD) on mathematical connection abilitiesstudents of SMP Negeri 5 Palembang.
\end{abstract}

Keywords: STAD, Mathematical,Connection,Ability

\section{PENDAHULUAN}

Pendidikan adalah suatu proses dalam rangka mempengaruhi siswa supaya mampu menyesuaikan diri sebaik mungkin dengan lingkungan dan dengan demikian akan menimbulkan perubahan dalam dirinya yang memungkinkannya untuk berfungsi secara bermanfaat dalam kehidupan masyarakat. Dalam dunia pendidikan siswa menghadapi berbagai proses pembelajaran yang dilaksanakan di dalam kelas maupun diluar kelas untuk mencapai suatu keberhasilan pendidikan.

Proses pembelajaran dilihat dari perkembangan kognitif yang dimulai 
dari anak usia sekolah dasar hingga jenjang pendidikan yang lebih tinggi pada umumnya yang mengalami kesulitan dalam memahami matematika yang bersifat abstrak. Karena keabstrakannya matematika relatif tidak mudah untuk dipahami siswa pada umumnya. Di mana proses pembelajaran matematika merupakan suatu proses belajar mengajar yang dibangun oleh guru untuk mengembangkan kreativitas berfikir siswa yang dapat meningkatkan kemampuan berpikir siswa, serta meningkatkan kemampuan mengkonstruksi pengetahuan baru sebagai upaya untuk meningkatakan penguasaan yang baik terhadap materi matematika. Pembelajaran dan Kurikulum merupakan hal yang tidak terpisahkan walaupun keduanya memiliki posisi yang berbeda. Kurikulum berfungsi sebagai pedoman yang memberikan arah dan tujuan pendidikan, sedangkan pembelajaran adalah proses yang terjadi dalam interaksi belajar dan mengajar antara guru dan siswa.Perkembangan kurikulum dari tahun ke tahun terus meningkat sesuai dengan tuntutan zaman. Kurikulum 2013 dalam proses pembelajaran matematika merupakan pelaksanaan program kurikulum ke dalam praktik atau proses pembelajaran matematika, sehingga terjadi perubahan dalam diri peserta didik baik perubahan pengetahuan, keterampilan maupun sikap. Kurikulum dalam proses pembelajaran terdiri dari tiga tahap yaitu perencanaan, tahan pelaksanaan dan tahap penilaian. Pembelajaran matematika dalam Kurikulum 2013 menekankan pada dimensi pedagogik modern dalam pembelajaran, yaitumenggunakan pendekatan ilmiah (scientific approach) meliputi mengamati, menanya, menalar, mencoba, membentuk jejaring untuk semua pelajaran. Selain itu, dalam kurikulum 2013 siswa dimotivasi untuk mengecek informasi baru dengan yang sudah ada dalam ingatan. Hal ini menyiratkan bahwa kurikulum matematika menekankan pada dimensi pedagogik dalam hal koneksi matematis.Menurut National Council of Teacher of Mathematics/NCTM (2000:67), terdapat lima kemampuan dasar matematika yang merupakan standar yakni pemecahan masalah (problem solving), penalaran dan bukti (reasoning and proff), komunikasi (communication), koneksi (connections), dan representasi (representation). Dalam penelitian ini digunakan salah satu standar kemampuan dasar matematika yaitu kemampuan koneksi (connections). NCTM menyebutkan koneksi matematis adalah keterkaitan aspek koneksi antar 
topik matematika, keterkaitan aspek koneksi dengan ilmu lain, dan keterkaitan aspek koneksi dengan dunia nyata siswa atau koneksi dengan kehidupan sehari - hari. Kemampuan koneksi matematika salah satu faktor penting dalam melakukan pemahaman konsep matematika, dengan melakukan koneksi konsep matematika yang telah dipelajari tidak ditinggalkan begitu saja tetapi digunakan sebagai pengetahuan dasar untuk memahami konsep yang baru.

Namun kemampuan koneksi matematis siswa disekolah masih tergolong rendah, ini di akibatkan karena siswa sulit menerapkan konsep yang telah dipelajari sebelumnya dengan konsep yang dipelajari selanjutnya, Sehingga dalam hal ini siswa kesulitan dalam memahami soal matematika yang diberikan oleh guru.Adapun faktor lain yang menyebabkan rendahnya kemampuan koneksi matematis siswa disebabkan oleh pembelajaran konvensional yang berpusat pada guru.

Salah satu cara untuk memperbaiki rendahnya kemampuan koneksi matematis dengan mengubah model pembelajaran yang biasa digunakan dengan model pembelajaran yang lebih menekankan siswa dalam merangsang dan mendorong kemampuan koneksi matematis siswa maka perlu diterapkan model pembelajaran lain yaitu model pembelajaran kooperatif tipe STAD. Menurut Kunandar STAD digunakan untuk mengajarkan informasi akademik baru kepada siswa setiap minggu, baik melalui verbal maupun tertulis, para siswa di dalam kelas dibagi menjadi beberapa kelompok yang bersifat heterogen baik jenis kelamin, ras, etnik maupun kemampuannya. Tiap anggota kelompok menggunakan lembar kerja akademik kemudian saling membantu untuk menguasai bahan ajar melalui tanya jawab atau diskusi antar sesama anggota kelompok.

Dari teori di atas, maka peneliti melakukan penelitian untuk mengetahui : apakah ada pengaruh pembelajaran kooperatif tipe Student Teams Achievement Divisions (STAD) terhadap kemampuan koneksi matematis siswa SMP Negeri 5 Palembang.

Berdasarkan uraian di atas, penelitian ini bertujuan untuk mengetahui ada atau tidaknya pengaruh pembelajaran kooperatif tipe Student Teams Achievement Divisions (STAD) terhadap kemampuan koneksi matematis siswa SMP Negeri 5 Palembang.

\section{METODE PENELITIAN}

Metode yang digunakan dalam penelitian ini adalah metode eksperimen.. Metodeeksperimen yang digunakan 
adalah metode True Experimental Design dengan bentuk Posttest-Only Control Design.

Penelitian ini dilaksanakan pada semester ganjil tahun ajaran 2018/2019, dengan lokasi penelitian di SMP Negeri 5 Palembang, subjek penelitian adalah siswa kelas VII. Teknik yang digunakan dalam pengambilan sampel pada penelitian ini adalah teknik Cluster Sampling. Dimana yang akan diambil berjumlah dua kelas dari seluruh kelas VIISMP Negeri 5 Palembang, dimana kelas VII.7 sebagai kelas Eksperimen dan kelas VII.8 sebagai kelas Kontrol.

\section{HASIL DAN PEMBAHASAN}

\section{Hasil Penelitian}

Pada bagian ini akan di deskripsikan hasil Post-test siswa pada masing-masing kelas, yaitu kelas eksperimen dengan model pembelajaran Student Teams Achievement Divisions (STAD) dan kelas kontrol dengan model pembelajaran konvensional.

Dari hasil penelitian ini adalah berupa rata-rata skor dari tes berbentuk uraian yang telah diberikan peneliti kepada seluruh siswa kelas VII.7 yang terdiri dari 30 siswa dan kelas VII.8 yang terdiri dari 29 siswa. Tes diberikan diakhir pembelajaran pada materi yang telah dipelajari pada pertemuanpertemuan sebelumnya, setelah itu data tes tersebut diberikan skor sesuai dengan pedoman penskoran koneksi matematis. Hasil tes akhir berupa skor selanjutnya dianalisis sesuai dengan pedoman penskoran kemampuankoneksimatematis. Setelah didapat nilai akhir dari setiap siswa, kemudian peneliti melakukan pembahasan dan membuat kesimpulan dari hasil penelitian tersebut.

Untuk mengetahui statistik data hasil tes akhir kemampuan koneksi matematis siswa pada kelas eksperimen dan kelas kontrol dapat dilihat pada Tabel 1 dibawah ini :

Tabel 1. Deskripsi Data Hasil Tes Kemampuan KoneksiMatematis

\begin{tabular}{ccc}
\multicolumn{3}{c}{ Kemampuan KoneksiMatematis } \\
\hline Kemampuan Koneksi \\
Statistik & \multicolumn{2}{c}{ Matematis } \\
& $\begin{array}{c}\text { Kelas } \\
\text { Eksperimen }\end{array}$ & $\begin{array}{c}\text { Kelas } \\
\text { Kontrol }\end{array}$ \\
N & 30 & 29 \\
Rata-rata & 66,17 & 56,90 \\
Max & 100,00 & 100,00 \\
Min & 40,00 & 30,00 \\
\hline
\end{tabular}

Berdasarkan Tabel 1 diatas, menunjukkan bahwa nilai rata-rata dan hasil tes akhir kemampuan koneksi matematis pada kelas eksperimen adalah 66,17 sedangkan nilai rata-rata pada kelas kontrol adalah 56,90. Hal ini terlihat bahwa kemampuan koneksi matematis pada kelas eksperimen lebih baik dari pada kelas kontrol.

\section{Analisis Data}

Dari soal tes akhiryang telah diberikan diberikan dikelas VII.7 dan kelas VII.8, jawaban siswa dianalisis 
Pengaruh Pembelajaran Kooperatif Tipestudent Teams Achievement Divisions (STAD) Terhadap Kemampuan Koneksi Matematis

untuk melihat kemampuan koneksi matematis siswa. Hasil analisis kemampuan koneksi matematis dapat dilihat pada Tabel 2 dibawah ini.

Tabel 2.Rata-Rata Kemampuan Koneksi Matematis SiswaPerindikator

\begin{tabular}{|c|c|c|c|}
\hline No & Indikator & $\begin{array}{l}\text { Ekspe } \\
\text { rimen }\end{array}$ & Kontrol \\
\hline 1 & $\begin{array}{l}\text { Memahami } \\
\text { representasi } \\
\text { ekuivalen dari } \\
\text { konsep yang sama. }\end{array}$ & 62,50 & 66,38 \\
\hline 2 & $\begin{array}{l}\text { Mencari dan } \\
\text { memahami koneksi } \\
\text { satu prosdur dengan } \\
\text { prosedur lain dalam } \\
\text { representasi yang } \\
\text { ekuivalen. }\end{array}$ & 69,58 & 57,76 \\
\hline 3 & $\begin{array}{l}\text { Menerapkan } \\
\text { matematika dalam } \\
\text { kehidupan sehari - } \\
\text { hari. }\end{array}$ & 76,67 & 55,17 \\
\hline 4 & $\begin{array}{l}\text { Menerapkan dan } \\
\text { menilai koneksi antar } \\
\text { topic matematika dan } \\
\text { koneksi di luar } \\
\text { matematika/ disiplin } \\
\text { ilmu lain. } \\
\quad \text { Rata-rata }\end{array}$ & 52,50 & 47,41 \\
\hline
\end{tabular}

Dari analisis data tes pada Tabel 2, diperoleh rata-rata kemampuan koneksi matematis siswa kelas eksperimen sebesar 66,31 lebih baik dari rata-rata kemampuan koneksi matematis siswa kelas kontrol sebesar 56,68. Artinya bahwa tingkat kemampuan koneksi matematis siswa dengan menggunakan pembelajaran kooperatif tipe Student Teams Achievement Divisions (STAD) lebih tinggi dibandingkan siswa yang menggunakan pembelajaran konvensional.
Namun hal ini belum dapat dipastikan apakah ada pengaruh rata-rata yang signifikan antara kelas eksperimen dan kelas kontrol. Karena itulah peneliti harus melakukan uji hipotesis untuk mengetahui apakah ada pengaruh ratarata yang signifikan antara kelas eksperimen dan kelas kontrol.

1. Uji Normalitas

Kriteria pengujian dikatakan berdistribusi normal apabila nilai signifikan atau nilai probabilitas (Signifikan) $>\alpha=0,05$ maka data dinyatakan berdistribusi normal dan nilai signifikan atau nilai probabilitas (Signifikan) $<\alpha=0,05$ maka data dinyatakan tidak berdistribusi normal. Hasil perhitungan data uji normalitas dapat dilihat pada tabel 3 dibawah ini:

Tabel 3. Hasil Uji Normalitas

Kemampuan Koneksi Matematis

\begin{tabular}{ccc}
\hline Kelas & Sig & Kesimpulan \\
Eksperimen & 0,200 & Data Berdistribusi \\
Kontrol & 0,200 & Normal \\
\hline
\end{tabular}

Berdasarkan Tabel 3 diperoleh nilai signifikan hasil perhitungan uji normalitas tes kemampuan koneksi matematis pada kelas eksperimen sebesar $0,200>0,05$ dan nilai signifikanpada kelas kontrol sebesar $0,200>$ 0,05 .berdasarkan kriteria pengujian maka data berdistribusi normal.

2. Uji Homogenitas 
Uji homogenitas data yang digunakan untuk menguji apakah kedua data tersebut sama (homogen) atau tidak (heterogen). Dalam penelitian ini homogenitas data di uji dengan menggunakan Software SPSS 22 yaitu dengan uji Statistik Levene's Test of Homogeneity of Variances.

Uji homogenitas dikatakan memenuhi asumsi bahwa variansnya homogen dengan ketentuan sebagai berikut : Jika probabilitas atau nilai Signifikan $\geq 0,05$ maka varians sampel dinyatakan homogen. Jika probabilitas atau nilai Signifikan $<0,05$ maka varians sampel dinyatakan tidak homogen.

Pada Tabel 4 terdapat tabel uji homogenitas menggunakan uji Statistik Levene's Test of Homogeneity of Variances.

Tabel 4.Hasil Uji Homogenitas Data

\begin{tabular}{|c|c|c|c|}
\hline \multicolumn{4}{|c|}{ Kemampuan Koneksi Matematis } \\
\hline$d f 1$ & $d f 2$ & Sig & Kesimpulan \\
\hline 1 & 57 & 0,548 & Homogen \\
\hline
\end{tabular}
bantuan SPSS versi 22 diatas, diperoleh nilai signifikan tes kemampuan koneksi matematis siswa adalah $0,548>$ 0,05.berdasarkan kriteria maka data tes kemampuan koneksi matematis dari kelas eksperimen dan kelas kontrol sama memiliki varians sama (homogen).

3. Uji Hipotesis
Setelah data memenuhi syarat yaitu data harus berdistribusi normal dan mempunyai varians yang sama maka pengujian dapat dilanjutkan dengan perhitungan menggunakan uji t yaitu Uji Independent Sampel T-Test dengan kriteria pengujian hipotesis, yaitu terima $\mathrm{H}_{0}$ jika nilai signifikan (2-tailed) $>0,025$ serta tolak $\mathrm{H}_{0}$ jika signifikan (2-tailed) $\leq$ 0,025. Adapun hasil uji Independent Sampel t-test menggunakan SPSS dapat dilihat pada tabel 5 berikut:

Tabel 5.Hasil Uji Hipotesis

\begin{tabular}{ccc}
\hline \multicolumn{3}{c}{ Kemampuan Koneksi Matematis } \\
$\boldsymbol{t}_{\text {hitung }}$ & $\boldsymbol{d} \boldsymbol{f}$ & Sig.(2-tailed) \\
2,418 & 57 & 0,019 \\
\hline
\end{tabular}

Berdasarkan hasil perhitungan uji-t pada tabel diatas dengan bantuan SPSS versi 22, tes kemampuan koneksi matematis diperoleh sig. (2-tailed) adalah $0,019<0,025$ berdasarkan kriteria pengujian maka $\mathrm{H}_{0}$ ditolak dan $\mathrm{H}_{\mathrm{a}}$ diterima sehingga disimpulkan bahwa "Ada pengaruh yang signifikan pembelajaran kooperatif tipe Student Teams Achievement Divisions (STAD) terhadap kemampuan koneksi matematis siswa SMP Negeri 5 Palembang”.

Dari hasil penelitian yang dilakukan peneliti melalui tes dengan cara memberikan tes di akhir pembelajaran. Hasil kemampuan koneksi matematis siswa yaitu dengan 
Pengaruh Pembelajaran Kooperatif Tipestudent Teams Achievement Divisions (STAD) Terhadap Kemampuan Koneksi Matematis

pembelajaran kooperatif tipe Student Teams Achievement Divisions (STAD) lebih besar dari pada kemampuan koneksi matematis siswa yang menggunakan pembelajaran konvensional.

Hasil kemampuan koneksi matematis adalah penskoran koneksi matematis siswa yang diperoleh dengan melakukan tes akhir (posttest) yang terdiri dari 5 soal yang mengacu pada indikator koneksi matematis mencakup materi bilangan pecahan. Postest diberikan pada akhir pembelajaran dengan tujuan untuk mengetahui kemampuan koneksi matematis siswa.

Kemampuan koneksi matematis teridiri dari 4 indikator. Indikator 1 terdapat pada soal nomor 4 pada soal posstest, terlihat pada lembar siswa pada Gambar 1.

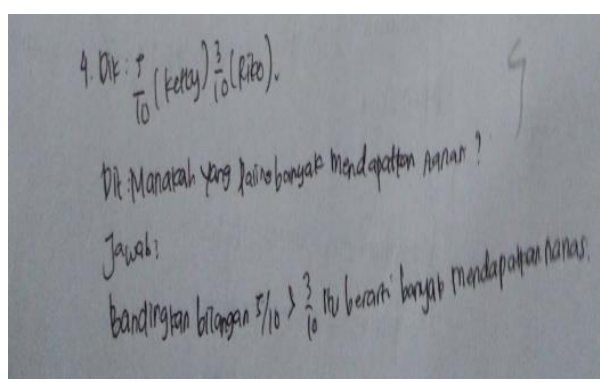

Gambar 1

Indikator 2 terdapat pada lembar siswa soal nomor 1 terlihat pada Gambar 2.

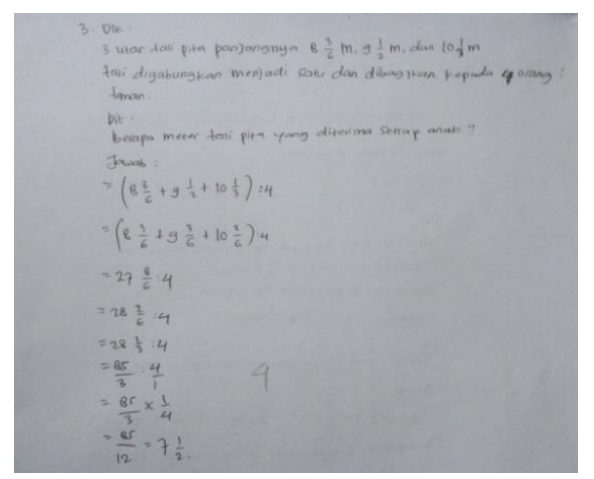

\section{Gambar 2}

Indikator ke 3 yaitu terdapat pada lembar siswa pada soal nomor 2 terlihat pada Gambar 3.

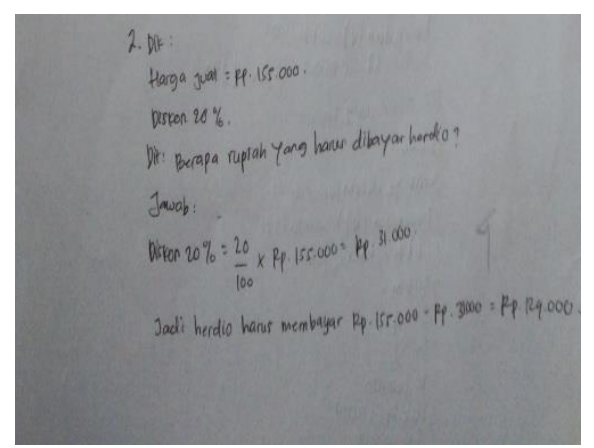

Gambar 3

Indikator ke 4 terdapat pada lembar siswa pada soal nomor 5 terlihat pada gambar 4.

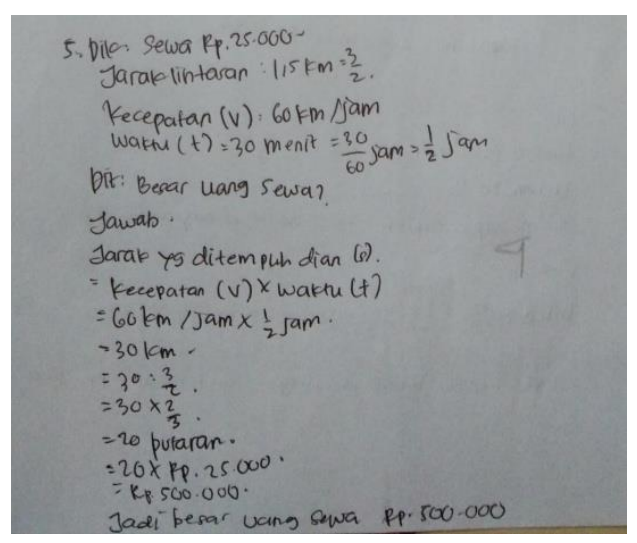

\section{Gambar 4}

Rata-rata kemampuan koneksi matematis siswa per indikator pada kelas eksperimen dan kelas kontrol. Soal posttest satu soal terdiri dari 1 indikator, dapat dilihat nilai rata-rata paling tinggi pada kelas eksperimen adalah terletak pada indikator ke- 3 yaitu 76,67 karena indikator ke-2 terdapat pada soal 2. Ratarata paling rendah terletak pada indikator ke-4 yaitu 52,50 sedangkan untuk kelas kontrol nilai rata-rata paling tinggi 
terletak pada indikator ke-1 yaitu 66,38 dan rata-rata paling rendah terletak pada indikator ke-4 yaitu 47,41. Dengan demikian dapat disimpulkan bahwa nilai rata-rata kemampuan koneksi matematis siswa kelas eksperimen lebih baik dibandingkan dengan kelas kontrol.

Dari data diatas menunjukan perolehan persentase skor kemampuan koneksi matematis siswa pada kelas eksperimen dan kelas kontrol. Dilihat dari persentase di atas dapat disimpulkan bahwa : Kemampuan koneksi matematis siswa yang pembelajarannya menggunakan pembelajaran kooperatif tipe Student Teams Achievement Divisions (STAD) lebih baik dari pada siswa yang pembelajarannya menggunakan model pembelajaran konvensional. Perbedaan hasil posttest pada kelas eksperimen maupun kelas kontrol diperkuat dengan hasil uji-t. Berdasarkan hasil perhitungan uji-t, tes kemampuan koneksi matematis pada kelas eksperimen dan kelas kontrol diperoleh nilai sig. (2-tailed) $=0,019$. Karena nilai signifikan lebih kecil dari 0,025 maka $\mathrm{H}_{0}$ ditolak, sehingga dapat disimpulkan bahwa ada pengaruh yang signifikan pembelajaran kooperatif tipe Student Teams Achievement Divisions (STAD) terhadap kemampuan koneksi matematis siswa SMP Negeri 5 Palembang.
Berdasarkan hasil penelitian yang telah dilakukan hal ini selaras dengan penelitian yang dilakukan oleh Suprapto (2015) yang berjudul Pengaruh Model Pembelajaran Kooperatif Tipe STAD Terhadap Peningkatan Kemampuan Representasi Dan Pemecahan Masalah Matematis Siswa. Berdasarkan hasil penelitian dan analisis data dapat ditarik kesimpulan bahwa kemampuan representasi dan pemecahan masalah matematis siswa yang memperoleh pembelajaran kooperatif tipe STAD lebih baik dari pada siswa yang memperoleh pembelajaran konvensional.Kemudian sejalan dengan penelitian yang dilakukan oleh Herdiyanti, dkk (2013) yang berjudul Pengaruh Model Pembelajaran Kooperatif Tipe STAD Terhadap Kemampuan Komunikasi Matematis Siswa, Berdasarkan hasil penelitian dan pembahasan diperoleh kesimpulan bahwa model pembelajaran kooperatif tipe STAD berpengaruh terhadap kemampuan komunikasi matematis siswa. Pengaruh tersebut dilihat dari kemampuan komunikasi matematis siswa yang mengikuti pembelajaran kooperatif tipe STAD lebih tinggi dari pada kemampuan komunikasi matematis siswa yang menggunakan pembelajaran konvensional.Kemudian penelitian ini selaras juga dengan penelitian yang dilakukan Rendya, dkk (2012) yang 
Pengaruh Pembelajaran Kooperatif Tipestudent Teams Achievement Divisions (STAD) Terhadap Kemampuan Koneksi Matematis

berjudul Kemampuan Koneksi Matematis

Dan Metode Pembelajaran Quantum Teaching Dengan Peta Pemikiran. Berdasarkan hasil penelitian ini dapat disimpulkan bahwa kemampuan koneksi siswa setelah pembelajaran dengan Metode Quantum Teaching dengan peta pemikiran lebih baik dari pada sebelum penerapkan metode Quantum Teaching dengan peta pemikiran. Selain itu kemampuan siswa dalam aspek koneksi antar topik matematika (K1), dengan disiplin ilmu lain (K2), dengan kehidupan sehari - hari siswa (K3) selama diterapkannya pembelajaran dengan metode Quantum Teaching dengan peta pemikiran cendrung mengalami peningkatan. Dan selaras juga dengan penelitian yang dilakukan Lik Faiqotul Ulya, dkk yang berjudul Peningkatan Kemampuan Koneksi Matematis Dan Motivasi Belajar Siswa Menggunakan Pendekatan Kontekstual. Berdasarkan hasil penelitian dan pembahasan dapat disimpulkan bahwa pendekatan kontekstual lebih baik secara signifikan dari pada pendekatan konvensional pada materi pecahan dalam meningkatkan kemampuan koneksi matematis siswa, hal ini disebabkan oleh prinsip - prinsip dan karakteristik pendekatan kontekstual yang lebih inofatif, lebih sesuai dengan teori - teori belajar dan lebih mendukung untuk meningkatkan kemampuan koneksi matematis siswa karena sejalan dengan makna dari kemampuan koneksi itu sendiri.

Model pembelajaran kooperatif tipe STAD diberikan pada kelas eksperimen sedangkan untuk pembelajaran konvensioal diberikan pada kelas kontrol untuk melihat perbedaan antara kedua kelas. Dari hasil penelitian yang didapat, kelas eksperimen yang diberi model pembelajaran kooperatif tipe STAD mendapatkan hasil yang lebih baik dari kelas kontrol. Hal ini karena model pembelajaran STAD STAD merupakan salah satu tipe pembelajaran kooperatif yang menekankan pada aktivitas dan interaksi di antara siswa untuk saling memotivasi dan membantu dalam menguasai materi pelajaran untuk mencapai prestasi yang maksimal.

Sedangkan untuk kelas kontrol yang diberi perlakuan pembelajaran konvensional dalam bentuk metode ceramah, sehingga siswa tidak termotivasi dalam belajar dan membuat siswa jenuh. Materi yang disampaikan tidak sepenuhnya dimengerti oleh semua siswa, terkadang hanya satu atau dua siswa yang mengerti pada kelas kontrol. Hal ini menyebabkan hasil belajar siswa yang berbeda pada kelas eksperimen yang diberi model pembelajaran kooperati tipe STAD, dimana STAD siswa dibagi menjadi kelompok 
beranggotakan empat orang yang beragam kemampuan, jenis kelamin dan sukunya. Guru memberikan suatu pelajaran dan siswa - siswa didalam kelompok memastikan bahwa semua anggota kelompok itu bisa menguasai pembelajaran tersebut. Kemudian semua siswa menjalani kuis perseorangan tentang materi yang telah dipelajari dan pada saat itu mereka tidak boleh bekerja sama, nilai hasil kuis siswa diperbandingkan dengan nilai rata - rata mereka sendiri yang telah diperoleh sebelumnya kemudian siswa diberi hadiah berdasarkan pada seberapa tinggi peningkatan yang bisa mereka capai dari sebelumnya. Nilai - nilai tersebut dijumlah untuk mendapat nilai kelompok dan kelompok yang mencapai kriteria tertentu bisa mendapat serifikat atau hadiah.

Kesimpulan dari hasil penelitian yang dilakukan peneliti pada kelas eksperimen dan kelas kontrol, serta sejalan dengan kajian relevan maka pembelajaran dengan menggunakan model pembelajaran kooperatif tipe STAD lebih baik dibandingkan dengan pembelajaran konvensional.

\section{KESIMPULAN}

Berdasarkan analisis data penelitian, maka hasil dari penelitian ini dapat disimpulkan bahwa : Ada pengaruh pembelajaran kooperatif tipe Student
Teams Achievement Divisions (STAD) terhadap kemampuan koneksi matematis siswa SMP Negeri 5 Palembang.

\section{DAFTARPUSTAKA}

Hamalik, Oemar. 2013. Kurikulum dan Pembelajaran. Jakarta : Bumi Aksara.

Herdiyanti, Zuma, dkk. 2016. PengaruhModel Pembelajaran Kooperatif Tipe STAD Terhadap Kemampuan Komunikasi Matematis Siswa. Jurnal Riset Dan Konseptual

Hidayah, Umi. 2015. Penerapan Model Pembelajaran Kooperatif Tipe Student Teams Achivement Divisions (STAD) Untuk Meningkatkan Hasil Belajar Matematika Siswa SMP Negeri 2 Tanjung Pura.Jurnal Pendidikan Matematika Paradikma

Kesumawati, Nila dan Ichwan Aridanu. 2017. Statistik Parametrik Penelitian Pendidikan. Palembang: NoerFikri.

Kuncara, Adi Wahyu, dkk.2014. Analisis Proses Pembelajaran Matematika Berdasarkan Kurikulum 2013 pada Materi Pokok Peluang Kelas X SMA Negeri 1 Surakarta.Jurnal Elektronik Pembelajaran Matematika

Linto, Rendya Logina, dkk. 2012. Kemampuan Koneksi Matematis Dan Metode Pembelajaran Quantum Teaching Dengan Peta Pemikiran.Jurnal Pendidikan Matematika

Musriliani, Cut, dkk. 2015. Pengaruh Pembelajaran Contextual Teaching Learning (CTL) Terhadap 
Pengaruh Pembelajaran Kooperatif Tipestudent Teams Achievement Divisions (STAD) Terhadap Kemampuan Koneksi Matematis

Kemampuan Koneksi Matematis Siswa SMP Ditinjau Dari Gender.Jurnal Didaktik Matematika

Nugraha, Agil Arif. 2018. Analisis Kemampuan Koneksi Matematis Siswa SMP Pada Materi Sistem Persamaan Linier Dua Variabel.Jurnal Suska Journal of Mathematics Education

Rawa, Natalia Rosalina, dkk.2016. Pengembangan Perangkat Pembelajaran Berbasis Model Learning CYCLE-7E Pada Materi Trigonometri Untuk Meningkatkan Kemampuan Koneksi Matematis SiswaJurnal Pendidkan : Teori, Penelitian, dan Pengembangan

Rusman.2016. Model - model Pembelajaran Mengembangkan Profesionalisme Guru. Jakarta : PT Raja Grafindo Persada.

Suprapto.2015. Pengaruh Model Pembelajaran Kooperatif Tipe STAD Terhadap Peningkatan Kemampuan Representasi Dan Pemecahan Masalah Matematis Siswa.Indonesian Digital Journal of Mathematics and Education

Surya, Edy dan Riska Rahayu.2014. Peningkatan Kemampuan Komunikasi Dan Pemecahan Masalah Matematis Siswa SMP AR - RAHMAN PERCUT Melalui Pembelajaran Kooperatif Tipe Student Teams Achivement Division (STAD).Jurnal Pendidikan PARADIKMA

Susanto, Ahmad. 2015. Teori Belajar dan Pembelajaran. Jakarta: Kencara. 